\title{
Culture in the post-2015 development agenda: the anatomy of an international mobilisation
}

\section{Antonios Vlassis}

To cite this article: Antonios Vlassis (2015) Culture in the post-2015 development agenda: the anatomy of an international mobilisation, Third World Quarterly, 36:9, 1649-1662, DOI: 10.1080/01436597.2015.1052064

To link to this article: http://dx.doi.org/10.1080/01436597.2015.1052064

曲 Published online: 25 Sep 2015.

Submit your article to this journal

山 Article views: 7

Q View related articles $\sqsubset$

View Crossmark data \lceil 


\title{
Culture in the post-2015 development agenda: the anatomy of an international mobilisation
}

\author{
Antonios Vlassis* \\ Centre for International Relations Studies (CEFIR), Department of Political Science, University of Liège, \\ Belgium \\ (Received 14 April 2015; final version received 13 May 2015)
}

Throughout 2012-15 several actors were advocating that culture be explicitly integrated within the post-2015 UN development agenda. My article offers an anatomy of the recent international mobilisation in order to understand the cleavages and the contrasting visions. In doing so, it seeks to analyse the policy process through which the agenda is made, why and how a critical mass of actors is attempting to embrace the inclusion of culture in the post-2015 agenda and the political reactions vis-à-vis this mobilisation. The article argues, on the one hand, that the promotion of culture in the post-2015 agenda is largely based on UNESCO's will to advance its policy agenda and enhance its position within the UN system and, on the other hand, that this mobilisation lacks political support from the most influential governments; therefore its chances of success are more than contingent.

Keywords: post-2015 development agenda; culture; UNESCO; global governance; UN system

Throughout $2012-15$ the United Nations political arena was strongly dominated by the international debate on the post-2015 agenda on the Sustainable Development Goals (SDGs), replacing the Millennium Development Goals (MDGs). ${ }^{1}$ At this time several actors were advocating that culture should play an essential role in the social, environmental and economic development pillars of sustainable development, and therefore should be explicitly integrated within the post-2015 development agenda. ${ }^{2}$ In the context of the thematic debate on 'Culture and Development' held at the UN General Assembly in 2013, the United Nations Educational, Scientific and Cultural Organization (UNESCO) Director-General, Irina Bokova, emphasised: 'We need to fully acknowledge the power of culture, as we shape a new global agenda to follow 2015. No society can flourish without culture and there can be no sustainable development without it. ${ }^{3}$

*Email: antonios.vlassis@gmail.com 
A recently growing body of academic research examines various aspects of the link between culture and development, offering useful insights on the legal features of international cultural cooperation on development, ${ }^{4}$ the sociological and anthropological implications of culture in development, ${ }^{5}$ the impact of culture on national and regional development policies, ${ }^{6}$ and on the place of culture in the EU's development policy. ${ }^{7}$

On the other hand, recent research has not sufficiently explored the political aspects of the link between culture and development within the global governance of culture, and the main cleavages shaping policy outcomes. As such, my article offers an anatomy of the recent international mobilisation regarding the inclusion of culture within the future UN development agenda and attempts to understand the power asymmetries and contrasting visions among the actors involved. ${ }^{8}$ In doing so, it is mainly concerned with empirically analysing the policy process through which the agenda is made, ${ }^{9}$ why and how a critical mass of actors aims to embrace the inclusion of culture in the post-2015 agenda, as well as political reactions to this mobilisation.

Based on document analysis and on semi-structured interviews with many of the actors involved (high-ranking officials in UN agencies and national governments, cultural nongovernmental organisations), the article will address this issue in three steps. First, it highlights the interests and the strategies of UNESCO, which is considered a norm entrepreneur for the inclusion of culture in the development agenda. Second, it seeks to tease out the rise of a global coalition of actors sharing UNESCO's particular view on the link between culture and the SDGs. Third, it focuses on the resistance and reluctance of certain European and North American countries, which are regarded as a political obstacle towards this mobilisation.

\section{International organisations as norm entrepreneur: UNESCO and the 'culture-development' link}

Since the 1980s UNESCO - the only UN agency with a mandate in cultural affairs - has sought to feed the international debate on the links between culture and development. ${ }^{10}$ First, I aim to distinguish two periods of this debate: before and after the adoption of the 2003 Convention for the Safeguarding of Intangible Cultural Heritage $(\mathrm{CICH})$ and the 2005 Convention on the Protection and Promotion of the Diversity of Cultural Expressions (CDCE), representing UNESCO's important normative advance in cultural affairs. Second, I seek to emphasise UNESCO's actions in favour of the inclusion of culture in the future UN development agenda.

\section{Multilateral debate without a concrete framework}

Between 1980 and 1990 four UNESCO initiatives related to the link between culture and development took place: (1) the World Conference on Cultural Policies (Mondiacult), held in Mexico from 26 July to 6 August 1982 and attended by 960 participants from 126 states; (2) the "World Decade for Cultural Development' (1988-97), the most tangible result of the Mondiacult conference's effort to place culture at the heart of development; (3) the report Our 
Creative Diversity, elaborated by the World Commission on Culture and Development and published in 1995; and (4) the Stockholm Intergovernmental Conference on Cultural Policies for Development, entitled 'The Power of Culture' and held in 1998. These initiatives - based on UN debates on an alternative conception of development beyond its economic aspects, on the first publication of the Human Development Report in 1990 and on the Brundtland Report Our Common Future (1987), which focused on the concept of sustainable development - sought to integrate the cultural dimension into national and regional development policies. However, they did not advance far enough towards more prescriptive actions. The debates were thus limited to broad moral commitments, with no establishment of institutional mechanisms. In this sense, even if progress had been achieved, 'an overarching standard-setting framework and demonstration tools were nevertheless lacking'. 11

\section{The normative recognition of culture in development policies}

The adoption of the CSIH and the CDCE was a major step towards the normative and institutional recognition of the importance of culture in development policies. Both these international legal instruments focus on specific aspects of cultural diversity: the 2003 Convention deals with the safeguarding of intangible cultural heritage, meaning 'the practices, representations, expressions, knowledge, skills that communities, groups and, in some cases, individuals recognize as part of their cultural heritage', while the objective of the 2005 Convention consists of protecting and promoting the diversity of cultural expressions and it deals especially with the cultural goods and services produced and distributed by cultural industries. More specifically, as regards the CDCE, even though the main interest of its promoters, such as the French and Canadian governments, was to regulate the interface between 'trade and culture' and to offer an international culture-driven response to bilateral and multilateral trade agreements, ${ }^{12}$ the CDCE was the first multilateral legal instrument to include concrete provisions for the link between culture and development. ${ }^{13}$ The CDCE stipulates the integration of cultural industries into sustainable development (Article 13), ${ }^{14}$ and it aims to strengthen international cultural cooperation through various tools, such as expert and information exchange among the Parties (articles 9 and 19), collaborative arrangements (article 15), preferential treatment for developing countries (Article 16) and the setting up of an International Fund for Cultural Diversity (IFCD), a multi-donor voluntary fund established under Article 18. Between 2010 and 2015 the IFCD has supported 78 projects in 48 developing countries; the contributions received amount to US\$7.3 million. ${ }^{15}$

As a result of the CDCE's implementation, UNESCO has established two collaborative arrangements for the more dynamic inclusion of the cultural dimension in national development policies. First, in 2010 UNESCO and the European Commission adopted the first international project to make the CDCE operational at the country level, highlighting the emergence of a transnational partnership for the implementation of international norms. As such, they created an expert facility project, funded by the EU, in order to implement the CDCE through the strengthening of the system of governance for cultural industries in developing countries. In this respect the UNESCO-EU project has allocated 
$€ 1.2$ million to create a pool of 30 experts in public policy for cultural industries. Thirteen technical assistance missions were put in place in order to transfer knowledge and know-how to countries in Africa (Burkina Faso, Democratic Republic of the Congo, Kenya, Malawi, Mauritius, Seychelles, Niger), Latin America (Argentina, Honduras), Asia (Vietnam, Cambodia) and the Caribbean (Barbados, Haiti).

Second, from 2009 to 2013 UNESCO developed 'Culture for Development Indicators' (CDIS) with the financial support of the Spanish Agency of International Cooperation for Development (AECID). CDIS is a policy tool for highlighting the contribution of culture in the development process and for demonstrating its policy impact at the national level through 22 indicators. The scope was to analyse the role of the link between culture and development in seven policy dimensions: economy, education, governance, social participation, gender equality, communication and heritage. 'UNESCO and the Spanish programme sought to prove the input of culture for development. In fact, UNESCO has succeeded in measuring the importance of culture and to persuade many member states of the organisation.' ${ }^{16}$ The CDIS has been tested and implemented in 11 countries: four in Latin America (Uruguay, Peru, Equador, Colombia), four in Africa (Burkina Faso, Ghana, Namibia, Swaziland), two in Asia (Vietnam, Cambodia), and one in Europe (Bosnia and Herzegovina).

\section{Culture in the post-2015 development agenda: a political opportunity for UNESCO}

UNESCO has recently been acting as a "norm entrepreneur', ${ }^{17}$ and it is mobilising resources for including culture among the SDGs of the post-2015 agenda. It seeks to generate new notions about appropriate behaviour on international development aid, persuading a critical body of actors to adopt and promote the new principled idea. The reasons behind UNESCO norm entrepreneurship are related more to the particular interests and ambitions of the UNESCO secretariat than to external political pressure from the member states of the organisation. ${ }^{18}$

First, it should be noted that the UNESCO secretariat is seeking to promote the normative framework of the organisation on cultural affairs, and especially three multilateral legal instruments, the $2005 \mathrm{CDCE}$, the $2003 \mathrm{CICH}$ and the 1972 World Cultural Heritage Convention. The aim of including culture in the UN development agenda is to ensure a prominent position for these conventions within the normative UN framework.

Second, UNESCO is in a difficult financial and budgetary situation today as a result of the suspension in late 2011 of US contributions, representing more than $20 \%$ of the UNESCO budget. ${ }^{19}$ Moreover, a new audit report on UNESCO management, published in April 2013, pointed out that the reforms launched by the organisation before 2010 have been undertaken 'too slowly and inconsistently owing to a lack of strict governance' and that UNESCO suffers from 'ambiguous and therefore inefficient governance'. ${ }^{20}$ The inclusion of culture among the SDGs would thus enhance UNESCO's position within the UN system, preventing its isolation, ${ }^{21}$ and would also create more active policy synergies with other UN bodies and with the major actors in development funding, such as the World Bank and the EU. In this sense the inclusion of culture is 
aimed at stimulating the credibility of the organisation and ultimately at reinforcing its economic resources.

Third, and most importantly, the active involvement of the UNESCO secretariat in the current discussions on the future UN development agenda has been one of the main goals of the new UNESCO Director-General, Irina Bokova, who was elected in 2009. The inclusion of culture in the post-2015 agenda is strongly linked to Bokova's vision regarding the objectives of the organisation to play an essential and meaningful role within the UN system. In 2010 Bokova said: 'I wish UNESCO would take a better role and a better place in the UN system...it is at heart a very important turning point, with my new team, but also with the challenge of the MDGs to be dealt with by $2015,{ }^{22}$ Thus, while there is no mention at all of the post-2015 agenda within the UNESCO 200813 Medium-term Strategy, the organisation's contribution to the building of the development agenda is becoming an important part of the 2014-21 Medium-term Strategy. ${ }^{23}$

As a result, under Bokova's stewardship, UNESCO has expanded its strategies for disseminating the new principled idea to a critical mass of actors and for making itself better positioned towards other UN bodies also suffering from institutional and budgetary pressure, in order to claim a prominent place within the SDGs. It has done so using the following means:

(1) The adoption by the UN General Assembly of two resolutions on 'Culture and sustainable development' with special reference to the inclusion of culture in the post-2015 agenda. ${ }^{24}$ These resolutions were elaborated and proposed by the UNESCO secretariat and as a result of the intergovernmental negotiations in the UN Economic and Financial Committee (Second Committee); the UN General Assembly adopted them in December 2013 and 2014.

(2) The International Congress 'Culture: key to sustainable development' held in Hangzhou, China in May 2013, attended by 500 participants from 82 countries and organised by UNESCO with financial support from China. This was the first international congress specifically focusing on the linkages between culture and development since the Stockholm conference in 1998. It should be noted that the congress was mainly the fruit of a combined initiative by the UNESCO secretariat and the Hangzhou local authorities, which have developed strong links since the inscription of the West Lake Cultural Landscape of Hangzhou within the UNESCO World Heritage List in $2011 .^{25}$

(3) The publication of a report by the UNESCO Director-General outlining the initiatives undertaken by UN bodies such as the World Tourism Organization, World Bank and the UN Conference on Trade and Development (UNCTAD) with respect to the link between culture and sustainable development. The report ultimately aims to make recommendations for enhancing the transversal role of culture in the post-2015 development agenda and for building linkages between UNESCO and other UN bodies. ${ }^{26}$

(4) The third and special edition of the report on the creative economy co-published by UNESCO and the United Nations Development 
Programme (UNDP) through the UN Office for South-South cooperation, focusing specifically on how the cultural and creative industries are at the core of local creative economies in developing countries. Most importantly, on the one hand, the 2008 and 2010 reports on the creative economy were the fruit of a collaboration led by the UNCTAD and the UNDP, paying special attention to the economic contribution of culture in development policies. This approach was influenced by UNCTAD, which is a more economy-driven organisation, favouring statistical data, and a less fieldbased UN agency. On the other hand, UNESCO and UNDP elaborated the 2013 report using an approach based on the qualitative evidence and the impact of culture at grassroots level. ${ }^{27}$

(5) The two thematic debates on 'Culture and Development' organised by UNESCO and held at the UN General Assembly in June 2013 and May 2014 in order to make the actors involved aware of taking culture into account throughout the elaboration of the post-2015 agenda.

(6) The third UNESCO World Forum on Culture and Cultural Industries held in Florence in October 2014 and entitled 'Culture, creativity and sustainable development: research, innovation, and opportunities'. The participants in the forum signed the Florence Declaration, calling 'on governments to ensure the integration in the post-2015 development agenda of explicit targets and indicators dedicated to the contribution of culture'. ${ }^{28}$

\section{The rise of a global constellation of actors}

Several actors share the particular view of UNESCO on making culture a goal of the post-2015 development agenda. Three main types of actors can be distinguished: many of the countries in Asia, Latin America, Africa and the Pacific; international and regional organisations; and cultural nongovernmental organisations (NGOs). Clearly, their interactions are continuous and simultaneous and the borders between them are not always distinct.

First, under the patronage of UNESCO, the Indonesian government organised a World Culture Forum held in November 2013 in Bali and entitled 'The power of culture in sustainable development'. The major result of the forum has been the 'Bali Promise' seeking to emphasise the importance of culture in the formation of the post-2015 development agenda. In addition, many high representatives from developing countries participated in two special thematic debates on 'Culture and Development' held at the UN General Assembly. Among them were the ministers of foreign affairs from the Republic of Korea and Bangladesh, as well as the ministers of culture from Turkey, Vietnam, Mali, Morocco, Albania, Paraguay, Jamaica, Côte d'Ivoire, the Bahamas, Republic of Mauritania, Trinidad and Tobago, Cape Verde, Serbia, South Africa and El Salvador. In parallel, during the fourth meeting of the Open Working Group of the UN General Assembly on SDGs, 15 member states, on Peru's initiative, proposed the establishment of a 'Group of Friends on Culture and Development', launched in September 2013. As of October 2014 the Group comprised nearly 30 countries. $^{29}$ 
Second, the inclusion of culture among international development goals has become a major component of the agenda of many international and regional organisations and forums, as demonstrated by:

- The ministerial declaration of the 2013 high-level segment of the UN Economic and Social Council, entitled 'Science, technology and innovation, and the potential of culture, for promoting sustainable development and achieving the Millennium Development Goals' (December 2013).

- The Dhaka Ministerial Declaration on the Diversity of Cultural Expressions adopted by the ministers and representatives of governments from the Asia-Pacific region in May 2012, and the Brussels resolution 'No Future without Culture', adopted in October 2012 at the third meeting of African, Caribbean and Pacific (ACP) states' ministers of culture. ${ }^{30}$

- The Sao Paulo Declaration on Culture and Sustainability adopted by the ministers, secretaries of state and other authorities of culture of Argentina, Bolivia, Brazil, Ecuador, Chile, Paraguay, Peru and Uruguay (April 2012) and the eighth Joint Declaration of the Ministers of Culture of SouthEastern Europe, entitled 'Intangible cultural heritage and sustainable development' (October 2012).

- The Suriname declaration adopted by the ministers of culture of the Community of Latin American and Caribbean States (CELAC) in March $2013,{ }^{31}$ which reaffirms their full support for all efforts to include culture in the SDGs, as well as the Declaration of Port-au-Prince (Haiti) on cultural interdependence in the context of globalisation adopted by the sixth Interamerican Meeting of Ministers of Culture of the Organization of American States, with an explicit mention of 'the importance of considering culture in the Post-2015 Development Agenda in connection with the MDGs' (August 2014).

Third, in May 2014 seven powerful NGOs on cultural affairs - the International Federation of Arts Councils and Culture Agencies, the International Federation of Coalitions for Cultural Diversity, the Committee on Culture of the World Association of United Cities and Local Governments (UCLG), ${ }^{32}$ Culture Action Europe, the Arterial Network, the International Music Council, and the International Council on Monuments and Sites - published a declaration on the inclusion of culture in the SDGs and launched a transnational campaign, 'The future we want includes culture'. By February 2015 the declaration had reached 2200 signatories from 120 countries, including more than 800 organisations.

\section{Bringing the intergovernmental factor back in}

Yet it is by no means clear that the future UN development agenda will explicitly incorporate culture. Two official UN reports - the proposal of the 30-member Open Working Group of the UN General Assembly on the SDGs and the synthesis report of the UN Secretary General - were published in September and December 2014, respectively, highlighting the future orientations of the post2015 development agenda. Mentions of culture in the broadest sense in these 
documents are minor, whereas the cultural and creative industries are completely absent from them.

The recent reports do not entirely reflect the increasing international and transnational mobilisation and its ambitions. Obviously the inclusion of culture within the future UN development agenda faces a major political obstacle: the intergovernmental factor, namely the resistance and reluctance of the majority of European and North American governments, which are the major contributors to international development aid and the fundamental actors in agenda setting. It is illustrative that the special UN thematic debates on culture and development were marked by the quasi-absence of representatives from these countries. 'In New York, we meet a double reality. At the General Assembly, all the delegations are in favour of the inclusion of culture. Then, when we're going to deal with more concrete questions, culture is absent, the delegations don't care.' 33

The reasons are multiple: some countries such as the USA have also been very reluctant to adopt the culture-driven multilateral legal instruments. The $2003 \mathrm{CICH}$ has so far been ratified by 161 states and, by March 2015, 134 governments together with the EU had ratified the 2005 CDCE. However, the USA is not yet party to these conventions. More specifically, in the view of US administrations, the cultural industries have nothing to do with 'culture' and any financial and regulatory mechanism in this sector must be the least restrictive possible. In addition, since the early 1990s US administrations have been a proactive defender of the inclusion of cultural goods and services within the bilateral and multilateral free trade agreements. ${ }^{34}$ Therefore, the inclusion of different aspects of culture, such as the cultural and creative industries, or of intangible cultural heritage within the development agenda is largely irrelevant, according to the Obama administration.

Most importantly, where countries such as Canada and Spain are concerned, their policy agenda has been completely upset by the arrival of conservative parties in power. Since 2006 Canada, which was one of the main political entrepreneurs of the CDCE's adoption, has displayed great reluctance towards involvement in the cultural sector. The country has not contributed to the IFCD since 2009. Throughout 2008-12 the conservative government announced major budget cuts affecting public radio in Canada, the Canadian Conference of the Arts, the National Film Board, the Library and Archives of Canada and the Coalition for Cultural Diversity. Moreover, the Stephen Harper government is seeking to rationalise the objectives and economic resources of the future UN development agenda and to emphasise an operationalised agenda based on measurable targets and indicators. In this sense the inclusion of a 'broad and abstract thematic' such as culture is clearly not part of Canada's strategy. ${ }^{35}$ To this picture should be added the fact that the Canadian government has developed a strong mistrust of the UNESCO secretariat since the adhesion of Palestine as a full member of the organisation.

For its part Spain was previously very dynamic regarding international development cooperation on culture. In relation to the MDGs the AECID supported 18 joint programmes based on the 'culture and development' thematic with a financial allocation of \$95.6 million. Moreover, in 2009 Spain organised a symposium in Paris on 'Culture and development: a response to the challenges of the future?' and in 2010 it hosted an international seminar in Gerona on 
'Culture and development'. ${ }^{36}$ In both cases the aim was to contribute to including culture as a core feature of development policies. In contrast, since 2011 the arrival in power of the conservative party and the present public debt and deficit crisis have totally changed the Spanish agenda on development policies and the place of culture among key Spanish priorities. Spain, too, has not contributed to the IFCD since 2010.

Furthermore, culture has not so far featured among the main priorities of other EU member states. On the one hand, France, Italy, Greece and Croatia, which are very involved in the implementation of the UNESCO World Cultural Heritage Convention and of the $\mathrm{CICH},{ }^{37}$ are followers of UNESCO's actions within the UN arena, but they don't provide political leadership or overall support. Moreover, the regulation of digital cultural services, especially of ondemand audio-visual media services, such as catch-up TV or video-on-demand film services, has recently dominated the policy agenda of the French government - one of the CDCE's promoters - thereby making the inclusion of culture in the post-2015 agenda a secondary priority. As a result, the 15 th summit of the Organisation Internationale de la Francophonie (OIF), held on 29-30 November 2014, adopted on France's initiative a resolution on the 2005 CDCE and the need to adapt it to the digital era. ${ }^{38}$

On the other hand, the UK, ${ }^{39}$ The Netherlands and the Scandinavian countries, ${ }^{40}$ which are leading donor countries where international development aid is concerned, are sceptical about UNESCO's initiatives for the explicit inclusion of culture in the post-2015 agenda. It is no exaggeration to say that one of the counter-arguments is 'the risk of the cultural relativism'. ${ }^{41}$ In other words, several governments of 'developed' countries believe that culture could justify some policy practices that would be the reverse of the previous developing country commitments to some key priorities of the development agenda, such as human rights, the status of women or reducing inequality. 'The developed countries are afraid that the developing countries in the name of culture would not be respectful about human rights issues. Culture as a goal could be a barrier to other development goals. $^{, 42}$

The European Commission, as the agent of EU foreign policy, published a Communication in February 2015 on its views of the post-2015 agenda setting. ${ }^{43}$ It is indicative that there was no mention at all of culture in this document, proving that the EU is keeping its distance from UNESCO's activities, even though the 'European Agenda for culture in a globalizing world', launched by the Commission back in 2006 and adopted in 2007, stated explicitly that the EU would follow an approach 'consisting of the systematic integration of the cultural dimension and different components of culture in all external and development policies, projects and programmes'. ${ }^{44}$

\section{Conclusion}

By highlighting the ways in which UNESCO has sought to promote the inclusion of culture within the post-2015 agenda on SDGs, this article has examined UNESCO's capacity to act as a 'norm entrepreneur'. It argued that the UNESCO secretariat has placed itself in a strong position to promote culture within the agenda and to generate some new notions about appropriate 
behaviour on international development aid. In addition, a broad and composite coalition of several actors, such as Asian and ACP countries, international and regional organisations, and powerful cultural NGOs, has arisen, embracing the new principled idea. The promotion of culture in the post-2015 agenda is largely based both on UNESCO's ability to persuade a critical mass of actors about the important role of culture as a driver of sustainable development and on its desire to promote its particular interests and its policy agenda, and at the same time to enhance its credibility within the UN system vis-à-vis other UN bodies also lobbying for a better position for their policy agenda in the SDGs.

Nevertheless, 'the emergence of international norms is by its very nature a contested process and one that is a long-term endeavour' ${ }^{45}$ The article has illustrated the fact that this international and transnational mobilisation lacks wide political support among the most influential governments in the shaping of the agenda. The counter-arguments are various, such as the irrelevance of state intervention in the cultural sector, the broad and abstract character of culture, the risk of cultural relativism, and even the secondary place of culture among other priorities within the policy agenda of many countries. In this regard, the article has shown that several European and North American countries lack the political will to be norm entrepreneurs and to provide political leadership and substantial resources for the explicit inclusion of culture in the post-2015 development agenda. Therefore, the chances of success of the mobilisation are more than contingent.

In any case the UN Summit for the adoption of the post-2015 development agenda will take place from 25 to 27 September 2015. An interesting avenue for future research will be not merely the final place of culture in this agenda, but also the impact of the latter on how national governments and regional and international organisations design and implement policies regarding the link 'culture and sustainable development'.

\section{Acknowledgments}

I am grateful to Sebastian Santander, Chrysoula Lentzou, Destiny Tchéhouali and to the anonymous peer reviewers for their valuable comments on previous versions. An earlier version of this article was presented at the panel on 'Regional Organizations' of the International Studies Association's 56th Annual Convention, New Orleans, 19 February 2015.

\section{Funding}

Research for this article was carried out with support from the Fonds national de la Recherche Scientifique (FNRS-Belgium).

\section{Notes on contributor}

Antonios Vlassis is FNRS (Fonds National de la Recherche Scientifique) Research Fellow at the Centre for International Relations Studies (CEFIR), University of Liège. His work focuses on the global governance of culture, the regulation of the 'trade-culture' interface, and international and regional cultural cooperation. His $\mathrm{PhD}$ thesis was published in 2015 by Presses Universitaires de Liège as Gouvernance mondiale et culture: de l'exception à la diversité (with a foreword by Professor Gilbert Gagné). 


\section{Notes}

1. The MDGs are: (1) Eradicating extreme poverty and hunger; (2) Achieving universal education; (3) Promoting gender equality and empowering women; (4) Reducing child mortality; (5) Improving maternal health; (6) Combating HIV/AIDS and malaria; (7) Ensuring environmental sustainability; and (8) Developing a global partnership for development.

2. While culture seems to be a vague concept, these actors refer especially to the cultural and creative industries, as well as to tangible and intangible cultural heritage.

3. UNESCO, "At the UN General Assembly."

4. Santos-Duisenberg, "Article 14"; and Richieri Hanania and Ruiz Fabri, "International Cooperation."

5. Clammer, "Culture, Development, and Social Theory"; Da Costa, "Introduction"; and Mattelart, "New International Debates."

6. Troussard et al., "Article 16"; Guèvremont, "Integrating Culture"; and de Beukelaer, Developing Cultural Industries.

7. Loisen, "Mainstreaming Culture."

8. Vlassis, Gouvernance mondiale.

9. Avant et al., Who Governs the Globe?; and Smouts, Forêts tropicales.

10. Regarding the historical pathways of the 'culture-development' nexus and UNESCO's strategies, see Vlassis, "UNESCO, the Cultural Industries."

11. UNESCO, 2008-2013 Medium-term Strategy, 25.

12. Vlassis, "La mise en œuvre de la Convention."

13. Aylett, "An International Instrument."

14. Article 13: "Parties shall endeavour to integrate culture in their development policies at all levels for the creation of conditions conducive to sustainable development and, within this framework, foster aspects relating to the protection and promotion of the diversity of cultural expressions'.

15. Albornoz, "The International Fund"; and Vlassis, "Culture Development."

16. Interview with a high-ranking UN official, May 14, 2014.

17. According to Martha Finnemore and Kathryn Sikkink, norm entrepreneurs 'are critical for norm emergence because they call attention to issues or even "create" issues by using language that names, interprets, and dramatizes them. The construction of cognitive frames is an essential component of norm entrepreneurs' political strategies, since, when they are successful, the new frames resonate with broader public understandings and are adopted as new ways of talking about and understanding issues. In constructing their frames, norm entrepreneurs face firmly embedded alternative norms and frames that create alternative perceptions of both appropriateness and interest.' Finnemore and Sikkink, "International Norm Dynamics," 897. See also Pace, "Norm Shifting"; and Rushton, "The UN Secretary-General."

18. Vlassis, "L'UNESCO face à l'enjeu 'commerce-culture'."

19. The USA has put its contributions to UNESCO on hold following the majority vote on making Palestine a full member of the organisation. In fact, two US laws adopted in 1990 and 1994 prohibit the funding of any UN agency which grants full membership as a state to any organisation or group that does not have the internationally recognised attributes of statehood. In addition, 'statements by both Republican and Democratic Members of Congress clearly [have] indicated that there is little congressional interest in changing the law'. Shaefer, "What Palestinian Membership Means," 5.

20. UNESCO, Audit Report, 23.

21. The UNESCO 2014-21 Medium-term Strategy states explicitly that 'UNESCO cannot work in isolation. It must continue to work actively within the framework of the UN system at the global, regional and national levels, render its action as relevant as possible to the realization of internationally agreed development goals, such as the MDGs and the future post-2015 development goals, as well as of regional and national priorities and needs.' UNESCO, 2014-2021 Medium-term Strategy, 30.

22. UN News Centre, "Interview with Irina Bokova."

23. UNESCO, 2014-2021-Medium Term Strategy.

24. While the 2010 and 2011 Resolutions are entitled "Culture and Development" and there is no mention of the post-2015 development agenda, the titles of 2013 and 2014 resolutions include the term 'sustainable development' and make explicit references to the ongoing development agenda.

25. On the other hand, even though the federal Chinese authorities were in favour of organising a major world event, they were less enthusiastic about the Congress theme. It is indicative that no high-ranking Chinese official participated in the UN thematic debates on culture and development in 2013 or 2014. In addition, China is not yet a member of the UN Group of Friends on Culture and Development launched in September 2013.

26. UNESCO, UNESCO's Participation.

27. For a critical appraisal of the 2013 report, see de Beukelaer, "The UNESCO/UNDP 2013 Creative Economy Report."

28. UNESCO, Florence Declaration.

29. Albania, Argentina, Barbados, Bangladesh, Benin, Bosnia and Herzegovina, Brazil, Bulgaria, Croatia, Ecuador, El Salvador, France, Greece, Hungary, Indonesia, Italy, Jamaica, Mexico, Morocco, Mongolia, Nepal, Peru, Republic of Korea, Senegal, South Africa, Qatar, Tunisia, Turkey and Vietnam. 
30. The Caribbean countries have played an important role in the debate on the link between culture and sustainable development and in the forging of the future UN development agenda. In September 2013, at the closing session of the Conference 'Cameras of Diversity for a Culture of Peace: Thematic Debates on Developing the Caribbean Film Industry', 51 experts and specialists signed the Trinidad and Tobago Declaration. The Declaration states: 'Despite the growing body of analysis, statistics and mapping exercises on the relationship between culture, creative industries and economic development, the potentialities of culture in development are not yet fully understood. We recognize that most Caribbean States are strongly committed to defending the inclusion of culture in the international development agenda, and acknowledge the importance of strengthening creative industries.'

31. CELAC was created in December 2011 with the signature of the Declaration of Caracas. It consists of 33 countries in the Americas.

32. In 2004 the UCLG Committee on Culture established Agenda 21 for culture, the first document at a world level to set out the principles and commitments of cities and local governments for sustainable cultural development. At present, "more than 500 cities, territories and organizations all over the world are engaged in the Agenda 21 for culture and in the promotion of culture as the 4th pillar of sustainable development, unanimously approved at the UCLG World Congress held in Mexico in 2010'. The UCLG Culture Summit, 'Culture and Sustainable Cities', took place from 18 to 20 March 2015 in Bilbao and its Plenary 3 focused on 'The place of culture in the sustainable development goals'. See http://www. uclg.org/en/issues/culture.

33. Interview with a high-ranking UN official, May 15, 2014.

34. Vlassis and Richieri Hanania, "Effects of the Convention."

35. Interview with a high-ranking UN official, March 4, 2015.

36. The 2010 international seminar followed the 2009 symposium 'Culture and creativity: vectors for development', organised on the initiative of the European Commissioner for Development and Humanitarian Aid, Louis Michel. The symposium resulted in the adoption by some 250 artists and cultural professionals of the Brussels declaration for the reinforcement of the role of culture as a driver of development. Nevertheless, in 2011 many signatories of the declaration addressed a letter to the former president of the European Commission, José Manuel Barroso, regretting its limited uptake.

37. The List of Intangible Cultural Heritage includes 14 elements in Croatia, 13 in France, six in Italy and two in Greece. The World Heritage List incorporates 50 elements in Italy, 39 in France, 17 in Greece, and seven in Croatia.

38. OIF, Résolution sur la Convention.

39. The USA, Canada and the UK have not yet ratified the 2003 UNESCO CSIH and they are reluctant about including promotion of 'intangible cultural heritage' among the priorities of the international development agenda. Moreover, the UK, party to the CDCE since 2007, has not yet contributed to the resources of the IFCD.

40. It should be mentioned that Norway, Finland, Sweden, Denmark, and The Netherlands have not proposed any element for inscription within the List of Intangible Cultural Heritage, whereas they are parties to the 2003 UNESCO CSIH.

41. Interview with a high-ranking UN official, March 4, 2015.

42. Interview with a high-ranking UN official, February 17, 2015.

43. Commission of the European Communities, Communication on a Global Partnership.

44. Commission of the European Communities, Communication on a European Agenda, 10.

45. Rushton, "The UN Secretary-General," 106.

\section{Bibliography}

Albornoz, Luis. "The International Fund for Cultural Diversity: A New Tool for Cooperation in the Audiovisual Field." International Journal of Cultural Policy (2015). Epub ahead of print, February 16, 2015. doi: 10.1080/10286632.2015.1008467.

Avant, Deborah D., Martha Finnemore, and Susan K. Sell. Who Governs the Globe? Cambridge: Cambridge University Press, 2010.

Aylett, Holly. "An International Instrument for International Cultural Policy: The Challenge of UNESCO's Convention on the Protection and Promotion of the Diversity of Cultural Expressions 2005." International Journal of Cultural Studies 13, no. 4 (2010): 355-373.

de Beukelaer, Christiaan. "The UNESCO/UNDP 2013 Creative Economy Report: Perks and Perils of the Evolving Agenda." Journal of Arts Management, Law and Society 44, no. 2 (2014): 90-100.

de Beukelaer, Christiaan. Developing Cultural Industries: Learning from the Palimpsest of Practice. Amsterdam: European Cultural Foundation, 2014.

Clammer, John. "Culture, Development, and Social Theory: On Cultural Studies and the Place of Culture in Development.” Asia Pacific Journal of Anthropology 6, no. 2 (2005): 100-119.

Commission of the European Communities. Communication on a European Agenda for Culture in a Globalizing World. COM (2007) 242 final. Brussels, May 10, 2007. 
Commission of the European Communities. Communication on a Global Partnership for Poverty Eradication and Sustainable Development after 2015. COM (2015) 44 final. Brussels, February 5, 2015.

Da Costa, Dia. "Introduction: Relocating Culture in Development and Development in Culture." Third World Quarterly 31, no. 4 (2010): 501-522.

Finnemore, Martha, and Kathryn Sikkink. "International Norm Dynamics and Political Change." International Organization 52, no. 4 (1998): 887-917.

Guèvremont, Vèronique. "Integrating Culture in Sustainable Development: Quebec's Agenda 21 - A Model for the Implementation of Article 13." In Cultural Diversity in International Law: The Effectiveness of the UNESCO Convention on the Protection and Promotion of the Diversity of Cultural Expressions, edited by Lilian Richieri Hanania, 265-278. London: Routledge, 2014.

Loisen, Jan. "Mainstreaming Culture in EU External Relations through Protocols on Cultural Cooperation: Fostering or Faltering Cultural Diversity?" In The Palgrave Handbook of European Media Policy, edited by Karen Donders, Caroline Pauwels and Jan Loisen, 509-525. London: Palgrave Macmillan, 2014.

Mattelart, Armand. "New International Debates on Culture, Information and Communication." In The Handbook of Political Economy of Communications, edited by Janet Wasko, Graham Murdock and Helena Sousa, 501-520. Chichester: Wiley Blackwell, 2011.

OIF. Résolution sur la Convention de l'UNESCO sur la protection et la promotion de la diversité des expressions culturelles. XVe Conférence des Chefs d'État et de Gouvernement des pays ayant le français en partage [Fifteenth Conference of Heads of State and Government with French as a common language]. Dakar, November 29-30, 2014.

Pace, Michelle. "Norm Shifting from EMP to ENP: The EU as a Norm Entrepreneur in the South?" Cambridge Review of International Affairs 20, no. 4 (2007): 659-675.

Richieri Hanania, Lilian, and Hélène Ruiz Fabri. "International Cooperation on Development and the Convention on the Diversity of Cultural Expressions." In The UNESCO Convention on the Diversity of Cultural Expressions: A Tale of Fragmentation in International Law, edited by Toshiyuki Kono and Steven Van Uytsel, 333-361. Cambridge: Intersentia, 2012.

Rushton, Simon. "The UN Secretary-General and Norm Entrepreneurship: Boutros Boutros-Ghali and Democracy Promotion." Global Governance 14, no. 1 (2008): 95-110.

Santos-Duisenberg, Edna. "Article 14: Cooperation for Development." In The UNESCO Convention on the Protection and Promotion of the Diversity of Cultural Expressions: Explanatory Notes, edited by Sabine von Schorlemer and Peter-Tobias Stoll, 371-391. New York, NY: Springer, 2012.

Smouts, Marie Claude. Forrets tropicales, jungle internationale: les revers d'une écopolitique internationale. Paris: Presses de Sciences Po, 2001.

Shaefer, Brett D. "What Palestinian Membership Means for UN and the Rest of the United Nations." Press release no. 2633. Heritage Foundation, December 12, 2011. http://thf_media.s3.amazonaws.com/2011/pdf/ bg2633.pdf.

Troussard, Xavier, Valérie Panis-Cendrowicz, and Julien Guerrier. "Article 16: Preferential Treatment for Developing Countries." In The UNESCO Convention on the Protection and Promotion of the Diversity of Cultural Expressions: Explanatory Notes, edited by Sabine von Schorlemer and Peter-Tobias Stoll, 405-455. New York, NY: Springer, 2012.

UN News Centre. “Interview with Irina Bokova Director of UNESCO.” Paris, 2010. http://www.un.org/apps/ news/newsmakers.asp?NewsID $=21$.

UNESCO. 2008-2013 Medium-term Strategy. 34 C/4. Paris: UNESCO, 2008.

UNESCO. 2014-2021 Medium Term Strategy. 37 C/4. Paris: UNESCO, 2014

UNESCO. "At the UN General Assembly, Culture takes Centre Stage in the 2015 Development Agenda." Paris, 2013. http://en.unesco.org/post2015/news/un-general-assembly-culture-takes-centre-stage-2015-de velopment-agenda.

UNESCO. Audit Report: Management of UNESCO's Budgetary and Financial Crisis - Impacts of on-going Reforms, Emergency and the Resultant Structural Measures. 191 EX/28, Part II. Paris: UNESCO, 2013.

UNESCO. Florence Declaration: Third UNESCO World Forum on Culture and Creative Industries. Paris, 2014.

UNESCO. UNESCO's Participation in the Preparations for a Post-2015 Development Agenda: Report of the Director General of the United Nations Educational, Scientific and Cultural Organization on Culture and Development. 192 EX/8.INF. Paris: UNESCO, 2013.

Vlassis, Antonios. "UNESCO, the Cultural Industries and the International Development Agenda: Between Modest Recognition and Reluctance." In Art and International Development, edited by Polly Stupples and Katerina Teaiwa. London: Routledge, forthcoming November 2015.

Vlassis, Antonios. Gouvernance mondiale et culture: De l'exception à la diversité. Liège: Presses Universitaires de Liège, 2015.

Vlassis, Antonios. "Culture Development in Technical and Financial Assistance on the Basis of the Convention." In Cultural Diversity in International Law: The Effectiveness of the UNESCO Convention on the Protection and Promotion of the Diversity of Cultural Expressions, edited by Lilian Richieri Hanania, 167-180. London: Routledge, 2014.

Vlassis, Antonios. 'L'UNESCO face à l'enjeu 'commerce-culture': Quelle action politique pour une organisation internationale?" Politique et Sociétés 32, no. 3 (2013): 81-101. 
Vlassis, Antonios. "La mise en œuvre de la Convention sur la diversité des expressions culturelles: portée et enjeux de l'interface 'commerce-culture'." Études Internationales 42, no. 4 (2011): 493-510.

Vlassis, Antonios, and Lilian Richieri Hanania. "Effects of the Convention on Trade Negotiations." In Cultural Diversity in International Law: The Effectiveness of the UNESCO Convention on the Protection and Promotion of the Diversity of Cultural Expressions, edited by Lilian Richieri Hanania, 25-39. London: Routledge, 2014. 